\title{
Effects of growth substrate and partial removal of nucleic acids in the production of bacterial protein meal on amino acid profile and digestibility in $\operatorname{mink}^{*}$
}

\author{
A. Skrede ${ }^{1,2,3}$, L.T. Mydland ${ }^{1,2}$ and M. Øverland ${ }^{1,2}$ \\ ${ }^{1}$ Norwegian University of Life Sciences, Department of Animal and Aquacultural Sciences \\ P.O. Box 5003, N-1432 As, Norway \\ ${ }^{2}$ Aquaculture Protein Centre \\ CoE, As, Norway
}

(Received 23 January 2009; revised version 30 April 2009; accepted 6 November 2009)

\begin{abstract}
Effects of growth substrate and nucleic acid reduction in the production of bacterial protein meal (BPM) were studied using a bacteria culture containing mainly Methylococcus capsulatus (Bath). BPM were produced on natural gas ( $>90 \%$ methane) (BPMG), methanol (BPMM), or methanol followed by nucleic acid reduction (BPMM-NAR). BPMG and BPMM had similar crude protein $(\mathrm{CP})$ and amino acid contents, whereas BPMM-NAR had slightly higher $\mathrm{CP}$ and amino acid contents. Digestibility of CP and amino acids in mink was higher for BPMM than for BPMG. Tryptophan revealed the greatest difference in true digestibility $(70.5 \%$ for BPMG vs $89.5 \%$ for BPMM) and lysine the least difference (93.2\% for BPMG and $95.7 \%$ for BPMM). There were no differences in CP or amino acid digestibility between BPMM and BPMM-NAR. It was concluded that BPM grown on methanol gave higher digestibility of CP and amino acids than natural gas, probably due to lower proportion of bacterial intracellular membrane protein.
\end{abstract}

KEY WORDS: bacterial protein, natural gas, methanol, amino acids, nucleic acids, digestibility, mink

\footnotetext{
*Supported by Research Council of Norway, Grant No. 143196/140 "Protein produced from natural gas - a new feed resource for fish and domestic animals", and by Norferm AS

${ }^{3}$ Corresponding author: e-mail: anders.skrede@umb.no
} 


\section{INTRODUCTION}

BioProtein ${ }^{\circledR}$ is a bacterial protein meal (BPM) grown by continuous aerobe fermentation of natural gas $(>90 \%$ methane). The final product is a reddish/ brownish meal, containing about, \%: dry matter (DM) 96, crude protein (CP) 70, lipids 10 and ash 7. The BPM has been reported to have a nutritionally favourable amino acid composition (Skrede et al., 1998), and to be a suitable protein source for pigs (Øverland et al., 2001), broiler chickens (Skrede et al., 2003; Schøyen et al., 2007), mink (Ahlstrøm et al., 2006) and salmonid fish species (Aas et al., 2006).

The bacterial culture used for BPM production consists of mainly Methylococcus capsulatus (Bath) and the heterotrophic bacteria Ralstonia sp., Aneurinibacillus sp., and Brevibacillus agri (Bothe et al., 2002). The methanotrophic bacteria $M$. capsulatus are found in nature where methane and oxygen are available, growing only on methane or methanol as the sole sources of carbon and energy. Oxidation of methane to methanol, catalysed by methane monooxygenase, is the first step in methane conversion (Hakemian and Rosenzweig, 2007). The BPM grown on natural gas has slightly lower digestibility of protein than high-quality fish meal, characteristically high digestibility of lysine and arginine and relatively low digestibility of cysteine and tryptophan (Skrede et al., 1998). In the studies by Kaushik and Luquet (1980), protein digestibility increased with increasing substitution of fish meal protein with bacterial protein produced on methanol as growth substrate. Thus, it seems interesting to study whether the use of methanol rather than methane in BPM production would improve nutrient digestibility.

The BPM contains about $7.6 \%$ RNA and $2.3 \%$ DNA on a dry matter basis (Skrede et al., 1998). The individual nucleobases in BPM have been shown to be highly digestible (Mydland et al., 2008). Nucleic acids are normal constituents of animal feed ingredients and nucleic acids from BPM seem to be efficiently digested and metabolized by several species, including pigs, mink and salmonid fish species (Aas et al., 2006; Ahlstrøm et al., 2006; Hellwing et al., 2007). In Atlantic salmon, the uricolytic pathway seems to be well regulated to handle high dietary purine levels. However, the level of nucleic acids in BPM is relatively high compared with the contents of most other protein sources, excluding other single cell proteins. This may limit the possibility of using intact BPM for human consumption, because humans lack the enzyme uricase due to two nonsense mutations in the urate oxidase gene.

The present work aimed at studying the effects of growth substrate in BPM production and partial removal of nucleic acids on amino acid composition and digestibility in mink as a model animal species. 


\section{MATERIALAND METHODS}

\section{Bacterial protein meal}

Three types of bacterial protein meal (BPM) produced by aerobe bacteria fermentation with mainly $M$. capsulatus (Bath) were produced by Norferm Danmark A/S, Odense (Denmark): type BPMG was grown on natural gas in a pilot scale fermentor, type BPMM was grown on methanol in a laboratory scale fermentor, and type BPMM-NAR was grown on methanol and subsequently nucleic acid reduced using heat shock at $90^{\circ} \mathrm{C}$ and activation of endogenous nucleases (Larsen and Joergensen, 1996).

\section{Animals and diets}

Digestibility experiments with mink (Mustela vison) were carried out at the Department of Animal and Aquacultural Sciences, The Norwegian University of Life Sciences, Ås. The animals were 7-month-old male mink of the standard genotype (initial body weight $2265 \pm 248 \mathrm{~g}$ ), randomly allotted to three groups of six animals each. Norwegian protocols of ethical standards concerning experiments involving animals were followed.

Wet diets with approximately $30 \%$ of metabolizable energy (ME) from protein, and containing BPMG, BPMM or BPMM-NAR as the sole sources of crude protein and amino acids, were used (Table 1). The diets were made one day prior to start of the experiment. Individual daily rations of $130 \mathrm{~g}$ wet weight, corresponding to about $50 \mathrm{~g} \mathrm{DM}$ and $1 \mathrm{MJ} \mathrm{ME}$, were weighed into plastic cups, frozen at $-20^{\circ} \mathrm{C}$ and stored at $-20^{\circ} \mathrm{C}$ until start of thawing in a refrigerator about $20 \mathrm{~h}$ before feeding.

Table 1. Ingredient composition of diets fed to mink

\begin{tabular}{|c|c|}
\hline Ingredients & $\mathrm{g} \mathrm{kg}^{-1}$ as fed \\
\hline Bacterial protein meal $^{1}$ & 194.2 \\
\hline Maize starch (precooked) & 91.9 \\
\hline Soyabean oil $^{2}$ & 87.2 \\
\hline Cellulose powder & 15.7 \\
\hline Vitamin and mineral premix ${ }^{3}$ & 1.0 \\
\hline Water $^{4}$ & 610.0 \\
\hline $\begin{array}{l}\text { grown on natural gas, methanol } \\
\text { A/S, Odense, Denmark); }{ }^{2} \text { De } \\
\text { Norway. Ingredients per kg, IU } \\
\text { vit. } B_{2} 3000 \text {, vit. B } 3000 \text {, vit } \\
300, \text { Fe (amino acid-chelated) } \\
{ }^{4} \text { added to achieve the same tot }\end{array}$ & $\begin{array}{l}\text { cid reduced (Norferm Danmark } \\
\text { rsk Mineralnæring, Hønefoss, } \\
\text { g: vit. E } 50000 \text {, vit. } B_{1} 15000 \text {, } \\
\text { cin } 5000 \text {, biotin } 30 \text {, folic acid } \\
15000 \text { and Cu sulphate } 1250 \text {; }\end{array}$ \\
\hline
\end{tabular}


The mink were housed individually in cages equipped for controlled feeding and quantitative faecal collection. The animals were fed the experimental diets during a 3-day preliminary period and a subsequent 4-day period for total collection of faeces. Feeding, collection of feed residues and collection of faeces were carried out once daily. The animals had free access to drinking water. Pooled faeces from each animal were freeze-dried, ground and sifted for removal of hair pending analysis.

\section{Chemical analysis}

Experimental diets and individually pooled faeces were freeze-dried and ground through a $0.5 \mathrm{~mm}$ screen. Dry matter $(\mathrm{DM})$, crude protein $(\mathrm{CP})$ (Kjeldahl $\mathrm{N} \times 6.25$ ) and ash were analysed according to standard procedures (AOAC, 1990). Crude fat content was determined by acid hydrolysis and subsequent petroleum ether extraction. Starch was determined according to McCleary et al. (1984). Amino acids, except tryptophan, were determined according to Method 994.12 of AOAC (1990) and tryptophan was determined according to Method 988.15 of AOAC (1990). Carbohydrate (CHO) content was calculated by subtracting protein $(\mathrm{N} \times 6.25)$, fat and ash from the dry matter content. Nucleic acids (DNA and RNA) in the bacterial protein meals were determined by the diphenylamine method and the orcinol method, respectively (Herbert et al., 1971).

\section{Calculations and statistics}

Apparent nutrient digestibility was determined as $((a-b) / a) \times 100$, where $a$ is nutrient intake and $b$ is amount of nutrient in faeces. The true digestibility of protein and amino acids was calculated using previously estimated correction values for endogenous excretion adjusted according to DM intake, obtained by feeding graded levels of protein and linear regression equations. One-way analysis of variance was used to determine effects of diets on digestibility, using each mink as the experimental unit. The results are presented as least square means (LSMEANS) for each diet, and standard deviation (SD) as a measure of the variance. Data from one animal fed the BPMM-NAR diet were omitted due to low feed intake. Duncan's multiple range test was used to test differences in digestibility between diets. The significance level was set to $\mathrm{P}<0.05$. 


\section{RESULTS AND DISCUSSION}

Proximate composition and amino acid profile. The contents of crude protein, fat, ash, DNA and RNA in BPMG (Table 2) agreed well with previously published data (Skrede et al., 1998). The BPMM contained similar levels of crude protein, fat, DNA and RNA compared with BPMG, whereas the starch content was lower and the ash content higher. The method used for reduction of nucleic acid contents to produce BPMM-NAR appeared to reduce ash levels in addition to reducing the DNA and RNA to about $1 / 3$ of the levels in BPMM. The increase in crude protein content associated with nucleic acid reduction may be associated

Table 2. Proximate composition and amino acid contents of bacterial protein meal grown on natural gas (BPMG) or methanol (BPMM), or grown on methanol and nucleic acid reduced (BPMMNAR)

\begin{tabular}{|c|c|c|c|}
\hline \multirow{2}{*}{ Treatment } & \multicolumn{3}{|c|}{ Diet } \\
\hline & BPMG & BPMM & BPMM-NAR \\
\hline \multicolumn{4}{|l|}{$\overline{\text { Proximate composition }}$} \\
\hline $\mathrm{DM}, \mathrm{g} \mathrm{kg}^{-1}$ & 941 & 940 & 947 \\
\hline \multicolumn{4}{|l|}{$g \mathrm{~kg}^{-1} \mathrm{DM}$} \\
\hline crude protein & 737 & 748 & 779 \\
\hline fat & 83 & 87 & 112 \\
\hline starch & 4.3 & 2.4 & 2.2 \\
\hline ash & 7.8 & 9.9 & 3.9 \\
\hline $\mathrm{CHO}$ & 10.3 & 6.6 & 7.0 \\
\hline DNA & 6.9 & 7.4 & 2.5 \\
\hline RNA & 2.0 & 2.3 & 0.8 \\
\hline \multicolumn{4}{|c|}{ Essential amino acids, $\mathrm{g} 16 \mathrm{~g}^{-1} \mathrm{~N}$} \\
\hline lysine & 5.2 & 5.3 & 5.5 \\
\hline threonine & 4.2 & 3.9 & 4.5 \\
\hline methionine & 2.2 & 2.2 & 2.5 \\
\hline tryptophan & 1.7 & 1.8 & 2.2 \\
\hline valine & 5.9 & 5.6 & 6.3 \\
\hline isoleucine & 4.5 & 4.1 & 4.7 \\
\hline leucine & 7.4 & 7.2 & 8.4 \\
\hline phenylalanine & 4.2 & 4.1 & 4.8 \\
\hline histidine & 2.2 & 2.2 & 2.5 \\
\hline arginine & 6.3 & 5.9 & 6.7 \\
\hline \multicolumn{4}{|c|}{ Non-essential amino acids, $g 16 \mathrm{~g}^{-1} \mathrm{~N}$} \\
\hline aspartic acid & 8.3 & 8.5 & 9.4 \\
\hline serine & 3.5 & 3.6 & 4.1 \\
\hline glutamic acid & 10.6 & 10.0 & 10.6 \\
\hline proline & 4.1 & 4.4 & 4.5 \\
\hline glycine & 4.8 & 4.6 & 5.1 \\
\hline alanine & 7.4 & 7.0 & 7.8 \\
\hline tyrosine & 3.7 & 3.7 & 4.2 \\
\hline cysteine + cystine & 0.6 & 0.6 & 0.7 \\
\hline
\end{tabular}


with loss of ash and carbohydrates and is in agreement with Larsen and Joergensen (1996).

The amino acid composition of BPMG, determined as g per $16 \mathrm{~g} \mathrm{~N}$ (percent of crude protein), agreed reasonably well with earlier analyses (Skrede et al., 1998), except for slightly lower values for lysine and methionine. BPMG and BPMM contained similar levels of all amino acids, thus the difference in growth medium appeared to have no major effect on amino acid composition. The BPMM-NAR, however, revealed generally higher amino acid contents than BPMG and BPMM. This reflected all amino acids and was an expected effect of the removal of nucleic acids, which contribute to the crude protein content when analysed as total nitrogen.

Digestibility. The apparent CP digestibility of BPMG (Table 3) was similar to values obtained by Skrede et al. (1998), but slightly lower than found by Schøyen et al. (2005) when using BPM from an industrial-scale production plant. The use of methanol as growth medium (BPMM) rather than natural gas (BPMG) resulted in higher apparent and true CP digestibility, whereas nucleic acid reduction had no effect on CP digestibility.

Table 3. Digestibility of main nutrients in mink fed diets containing bacterial protein meal grown on natural gas (BPMG) or methanol (BPMM) without or with subsequent nucleic acid reduction (BPMM-NAR) $)^{1}, \%$

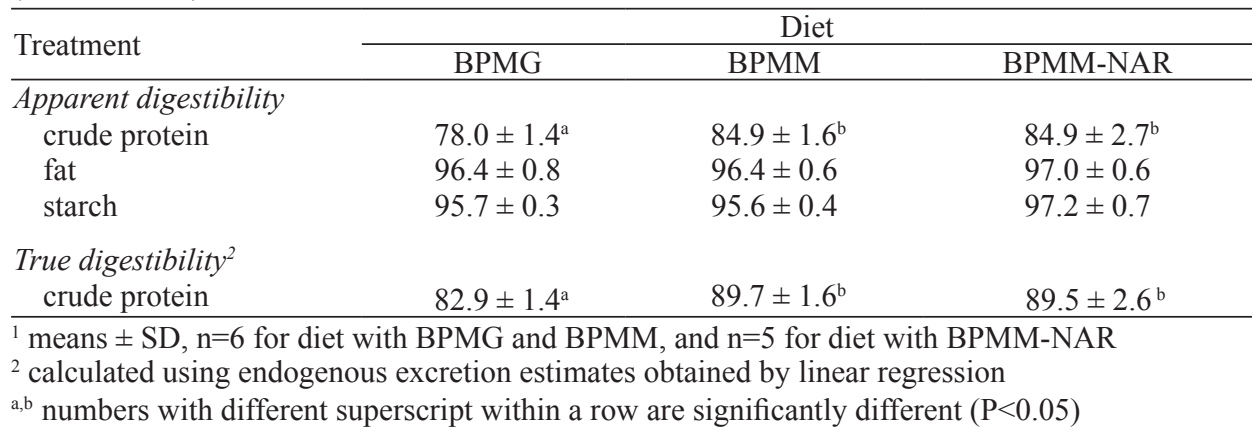

Digestibility of crude fat and starch was not affected by treatment (Table 3). In the present study, the investigated BPM sources contributed only small fractions of dietary fat and starch, as soyabean oil was the main fat source, and maize starch was the major starch source. Hence, effects of different bacterial protein sources on digestibility of fat and starch were not expected. However, it is interesting to note the tendency towards slightly higher starch digestibility $(\mathrm{P}=0.061)$ of the diet containing BPMM-NAR compared with the other diets.

The amino acid digestibilities of BPMG (Table 4) were generally in good agreement with those determined in previous experiments (Skrede et al., 1998). 
Thus, the high digestibilities of lysine and arginine, and the low digestibilities of cysteine and tryptophan were confirmed. The digestibilities of isoleucine and tyrosine were lower in the present study than found by Skrede et al. (1998).

Table 4. True digestibility ${ }^{1,2}$ of amino acids in mink fed bacterial protein meal grown on natural gas (BPMG) or methanol (BPMM) without or with subsequent nucleic acid reduction (BPMM-NAR), $\%$

\begin{tabular}{lccc}
\hline \multirow{2}{*}{ Treatment } & \multicolumn{3}{c}{ Diet } \\
\cline { 2 - 4 } Essential amino acids & BPMG & BPMM & BPMM-NAR \\
lysine & $93.2 \pm 1.2^{\mathrm{a}}$ & $95.7 \pm 0.9^{\mathrm{b}}$ & $96.0 \pm 1.3^{\mathrm{b}}$ \\
threonine & $85.6 \pm 2.7^{\mathrm{a}}$ & $90.0 \pm 2.8^{\mathrm{b}}$ & $90.4 \pm 4.2^{\mathrm{ab}}$ \\
methionine & $84.6 \pm 1.6^{\mathrm{a}}$ & $93.7 \pm 0.9^{\mathrm{b}}$ & $93.9 \pm 1.4^{\mathrm{b}}$ \\
tryptophan & $70.0 \pm 2.0^{\mathrm{a}}$ & $89.5 \pm 1.6^{\mathrm{b}}$ & $89.2 \pm 4.0^{\mathrm{b}}$ \\
valine & $88.8 \pm 1.0^{\mathrm{a}}$ & $94.5 \pm 1.1^{\mathrm{b}}$ & $94.0 \pm 1.5^{\mathrm{b}}$ \\
isoleucine & $81.9 \pm 1.2^{\mathrm{a}}$ & $91.7 \pm 1.4^{\mathrm{b}}$ & $89.8 \pm 2.0^{\mathrm{b}}$ \\
leucine & $84.2 \pm 1.5^{\mathrm{a}}$ & $92.9 \pm 1.3^{\mathrm{b}}$ & $92.5 \pm 1.7^{\mathrm{b}}$ \\
phenylalanine & $79.4 \pm 1.5^{\mathrm{a}}$ & $90.5 \pm 1.5^{\mathrm{b}}$ & $91.0 \pm 1.9^{\mathrm{b}}$ \\
histidine & $88.2 \pm 1.0^{\mathrm{a}}$ & $93.7 \pm 1.2^{\mathrm{b}}$ & $94.7 \pm 1.9^{\mathrm{b}}$ \\
arginine & $93.1 \pm 0.9^{\mathrm{a}}$ & $96.2 \pm 0.8^{\mathrm{b}}$ & $96.3 \pm 1.1^{\mathrm{b}}$ \\
Non-essential amino acids & & & \\
aspartic acid & $86.4 \pm 1.6^{\mathrm{a}}$ & $91.8 \pm 1.3^{\mathrm{b}}$ & $92.1 \pm 1.8^{\mathrm{b}}$ \\
serine & $83.3 \pm 2.2^{\mathrm{a}}$ & $89.7 \pm 2.1^{\mathrm{b}}$ & $90.8 \pm 3.1^{\mathrm{b}}$ \\
glutamic acid & $89.5 \pm 1.6^{\mathrm{a}}$ & $92.1 \pm 1.2^{\mathrm{b}}$ & $92.2 \pm 2.1^{\mathrm{b}}$ \\
proline & $86.0 \pm 2.6^{\mathrm{a}}$ & $91.1 \pm 2.3^{\mathrm{b}}$ & $90.3 \pm 3.6^{\mathrm{b}}$ \\
glycine & $84.0 \pm 1.8^{\mathrm{a}}$ & $91.2 \pm 1.3^{\mathrm{b}}$ & $90.7 \pm 2.1^{\mathrm{b}}$ \\
alanine & $87.1 \pm 0.8^{\mathrm{a}}$ & $94.1 \pm 0.9^{\mathrm{b}}$ & $91.7 \pm 2.0^{\mathrm{b}}$ \\
tyrosine \\
cysteine + cystine & $75.4 \pm 2.7^{\mathrm{a}}$ & $83.9 \pm 3.2^{\mathrm{b}}$ & $85.2 \pm 4.0^{\mathrm{b}}$ \\
\hline
\end{tabular}

${ }^{1}$ means \pm SD, $n=6$ for diet with BPMG and BPMM, and $n=5$ for diet with BPMM-NAR

2 calculated using endogenous excretion estimates obtained by linear regression

${ }^{a, b}$ numbers with different superscript within a row are significantly different $(\mathrm{P}<0.05)$

In studies by Kaushik and Luquet (1980) bacterial protein grown on methanol could be fed at high levels without adverse effects on growth rate and feed conversion ratio in rainbow trout. The amino acid digestibilities of BPMM and BPMM-NAR in the present study were significantly higher than those of BPMG, except for the highly variable cysteine + cystine digestibility. The greatest difference was seen with tryptophan, with a true digestibility of about $70 \%$ for BPMG and $90 \%$ for BPMM and BPMM-NAR. Amino acids with high digestibility in BPMG, i.e. lysine and arginine, were least affected by replacing natural gas with methanol as growth medium.

The improvement in digestibility of $\mathrm{CP}$ and amino acids obtained by using methanol instead of natural gas as carbon and energy source was probably related to morphological characteristics of the bacteria caused by different growing 
conditions, resulting in reduced proportions of membrane-bound protein. The main bacteria in BPM, $M$. capsulatus, contain a complex system of internal membranes when methane is used as carbon and energy source. The key enzyme in the methane metabolism is methane monooxygenase (MMO), which catalyses the oxidation of methane to methanol. M. capsulatus (Bath) possesses two forms of MMO; the membrane-associated or particulate (pMMO) and the soluble (sMMO), and their expression in the cell is dependent upon the copper-to-biomass ratio in the culture (Dalton, 2005). The "copper switch" induces a range of physiological changes, differences in gene expression and the formation of intracellular membranes.

To our knowledge no experiments have been performed to study the formation of intracellular membranes in M. capsulatus (Bath) when grown on methane vs methanol. However, Hyder et al. (1979) have shown that Methylococcus capsulatus (Texas), when grown on methane, accumulates intracellular membranes, as opposed to when grown on methanol, when virtually no internal membranes were present. This has also been demonstrated in another methanotrophic bacterium (Methylobacterium organophilum), where the intracellular membranes were present when cells were grown with methane, but not when grown with methanol or glucose as the sole source of carbon and energy (Patt and Hanson, 1978). Thus when methane-utilizing bacteria are grown on methanol these internal membranes are not present, or may be present to a lesser extent.

The amino acid digestibilities of an extract from autolysed BPM with reduced content of membranes have been shown to be higher than those of a crude autolysed BPM (Schøyen et al., 2005). This suggests that poor digestibility of membranebound amino acids contributed to the rather low digestibility of some amino acids in BPMG. Vesicle formation of membrane fractions and proteins embedded in the membranes may render amino acids unavailable for digestion (Schøyen et al., 2005). The peptidoglycans in the cell wall of bacteria may be resistant to proteases due to the presence of D-amino acids. This would explain why a lower content of cell membranes in BPMM than in BPMG seems to result in considerably higher amino acid digestibility.

The true amino acid digestibilities of BPMM-NAR were similar to those of corresponding amino acids in BPMM. Thus, the process developed by Larsen and Joergensen (1996) for partial removal of DNA and RNA had no influence on amino acid digestibility. Removal of nucleic acids from BPM grown on mainly $M$. capsulatus may, however, be unnecessary, and may even reduce nutritional value for several species, including pigs, mink and Atlantic salmon. The nucleic acids are converted in vivo by nucleases to nucleotides, nucleosides and nucleobases, and recent studies show efficient digestion and absorption of nucleic acids from BPM (Mydland et al., 2008). In pigs and mink, increased intake of nucleic acid nitrogen from BPM resulted in increased allantoin excretion (Hellwing et al., 
2007). However, increasing levels of BPM have been fed without significant effects on nitrogen retention in pigs (Hellwing et al., 2007) and mink (Hellwing et al., 2005, 2007; Ahlstrøm et al., 2006). Recent studies by Aas et al. (2006) showed higher nitrogen retention when bacterial protein meal partially replaced high-quality fish meal in diets for Atlantic salmon. The latter findings indicate that dietary nucleic acids may have a nitrogen-sparing effect, although nucleotides as well as non-essential amino acids are endogenously synthesized. Moreover, there is evidence that nucleotides have an important role as semiessential nutritional components (Sànchez-Pozo and Gil, 2002).

The average true amino acid digestibilities of BPMG, BPMM and BPMMNAR were $85.9,92.2$ and $92.0 \%$, respectively. These values were slightly higher than the corresponding true $\mathrm{CP}$ digestibilities, indicating that non-protein nitrogen was less efficiently digested than the amino acids. This difference was apparent also for BPMM-NAR, where the non-protein fraction accounted for a reduced proportion of total nitrogen. This may indicate that the nucleic acids were digestible to approximately the same extent as the amino acids, as shown by Mydland et al. (2008), whereas other non-protein constituents may have been less digestible.

\section{CONCLUSIONS}

Use of natural gas, consisting of mainly methane, or methanol as carbon and energy sources in the production of bacterial protein meal resulted in similar proximate composition and amino acid profile. Digestibility of crude protein and amino acids was significantly higher with methanol than with natural gas in the fermentation medium, most likely due to differences in morphology of the Methylococcus capsulatus cells. Reduction in nucleic acid content by endogenous nucleases had minor effects on amino acid composition and no effect on amino acid digestibility.

\section{REFERENCES}

Aas T.S., Grisdale-Helland B., Terjesen B.F., Helland S.J., 2006. Improved growth and nutrient utilisation in Atlantic salmon (Salmo salar) fed diets containing a bacterial protein meal. Aquaculture 259, 365-376

Ahlstrøm Ø., Tauson A.-H., Hellwing A.L.F., Mydland L.T., Skrede A., 2006. Growth performance, nitrogen balance and urinary excretion of purine derivatives in growing-furring mink (Mustela vison) fed bacterial protein meal produced from natural gas. J. Anim. Feed Sci. 15, 491-504

AOAC, 1990. Association of Official Analytical Chemists, Official Methods of Analysis. 15 $5^{\text {th }}$ Edition. Washington, DC 
Bothe H., Jensen K.M., Mergel A., Larsen J., Jørgensen C., Bothe H., Jørgensen L., 2002. Heterotrophic bacteria growing in association with Methylococcus capsulatus (Bath) in a single cell protein production process. Appl. Microbiol. Biotechnol. 59, 33-39

Dalton H., 2005. The Leeuwenhoek Lecture 2000. The natural and unnatural history of methaneoxidising bacteria. Phil. Trans. R. Soc. B 360, 1207-1222

Hakemian A.S., Rosenzweig A.C., 2007. The biochemistry of methane oxidation. Annu. Rev. Biochem. 76, 18.1-18.19

Hellwing A.L.F., Tauson A.-H., Ahlstrøm Ø., Skrede A., 2005. Nitrogen and energy balance in growing mink (Mustela vison) fed different levels of bacterial protein meal produced from natural gas. Arch. Anim. Nutr. 59, 335-352

Hellwing A.L.F., Tauson A.-H., Skrede A., Kjos N.P., Ahlstrøm Ø., 2007. Bacterial protein meal in diets for pigs and minks: Comparative studies on protein turnover and urinary excretion of purine base derivatives. Arch. Anim. Nutr. 61, 425-443

Herbert D., Phipps D., Strange R., 1971. Chemical analysis of microbial cells. In: J. Norris, D. Ribbons (Editors). Methods in Microbiology 5B. Academic Press, London, pp. 209-344

Hyder S.L., Meyers A., Cayer M.L., 1979. Membrane modulation in a methylotrophic bacterium Methylococcus capsulatus (Texas) as a function of growth substrate. Tissue Cell 11, 597-610

Kaushik S.J., Luquet P., 1980. Influence of bacterial protein incorporation and of sulphur amino acid supplementation to such diets on growth of rainbow trout, Salmo gairdnerii Richardson. Aquaculture 19, 163-175

Larsen J., Joergensen L., 1996. Reduction of RNA and DNA in Methylococcus capsulatus by endogenous nucleases. Appl. Microbiol. Biotechnol. 45, 137-140

McCleary B.V., Solah V., Gibson T.S., 1984. Quantitative measurements of total starch in cereal flours and products. J. Cereal Sci. 20, 51-58

Mydland L.T., Frøyland J.R.K., Skrede A., 2008. Composition of individual nucleobases in diets containing different products from bacterial biomass grown on natural gas, and digestibility in mink (Mustela vison). J. Anim. Physiol. Anim. Nutr. 92, 1-8

Øverland M., Skrede A., Matre T., 2001. Bacterial protein grown on natural gas as feed for pigs. Acta Agr. Scand., Sect. A, Anim. Sci. 51, 97-106

Patt T.E., Hanson R.S., 1978. Intracytoplasmic membrane, phospholipid, and sterol content of Methylobacterium organophilum cells grown under different conditions. J. Bacteriol. 134, 636644

Sànchez-Pozo A., Gil A., 2002. Nucleotides as semiessential nutritional components. Brit. J. Nutr. 87, Suppl. 1, S135-S137

Schøyen H.F., Hetland H., Rouvinen-Watt K., Skrede A., 2007. Growth performance and ileal and total tract amino acid digestibility in broiler chickens fed diets containing bacterial protein meal grown on natural gas. Poultry Sci. 86, 87-93

Schøyen H.F., Kringeland J.R.F., Sahlstrøm S., Knutsen S.H., Skrede A., 2005. Effects of autolysis and hydrolysis of bacterial protein meal grown on natural gas on chemical characterisation and amino acid digestibility. Aquaculture 248, 27-33

Skrede A., Berge G.M., Storebakken T., Herstad O., Aarstad K.G., Sundstøl F., 1998. Digestibility of bacterial protein grown on natural gas in mink, pigs, chicken and Atlantic salmon. Anim. Feed Sci. Tech. 76, 103-116

Skrede A., Schøyen H.F., Svihus B., Storebakken T., 2003. The effect of bacterial protein on growth performance and sensory quality of broiler chickens. Can. J. Anim. Sci. 83, 229-237 